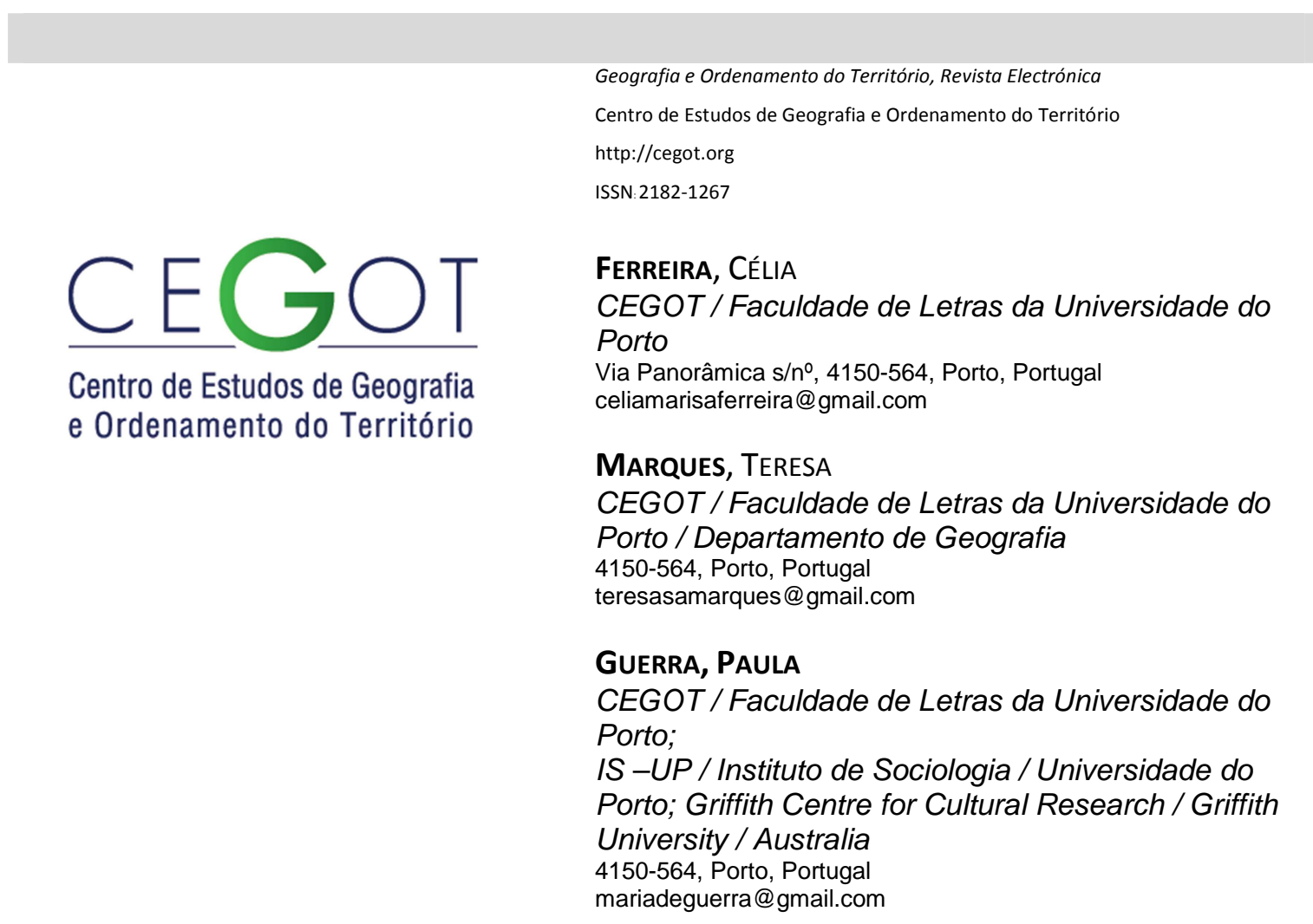

\title{
Feiras e mercados no Porto: velhos e novos formatos de atividade económica e animação urbana
}

Fairs and markets in Oporto: old and new formats of economic activity and urban animation

Referência: Ferreira, Célia et al. (2015). Feiras e mercados no Porto: velhos e novos formatos de atividade económica e animação urbana. Revista de Geografia e Ordenamento do Território (GOT), n.o 8 (dezembro). Centro de Estudos de Geografia e Ordenamento do Território, p. 75-102, dx.doi.org/10.17127/got/2015.8.005

\section{RESUMO}

Apesar da escassez de literatura científica sobre feiras e mercados urbanos, esta atividade económica é reconhecida por instituições internacionais e organismos locais como uma força motriz do desenvolvimento económico local e das vivências e animação urbanas. Com esta pesquisa pretende-se dar um contributo para a investigação nesta área, através da análise dos mercados e feiras existentes oficialmente na cidade do Porto. A abordagem metodológica assenta na observação, na realização de um conjunto de entrevistas e em fontes complementares. O objetivo é analisar os formatos, as características, as parcerias, o envolvimento com a comunidade local e as estratégias de marketing e comunicação das feiras e mercados urbanos. 
Palavras-chave: Mercados urbanos, Feiras de rua, Feiras de artesanato, Cidade do Porto, Dinâmicas económicas, Vivências culturais, Animação urbana

\section{ABSTRACT}

Despite the scarcity of scientific literature on urban fairs and markets, this economic activity is recognized by international institutions and local bodies as a driver of local economic development and urban experiences and animation. This research is intended to make a contribution to the study of this issue by analyzing the official markets and fairs that exist in Oporto. The methodological approach is based on observation, interviews and complementary sources. The goal is to analyze the format, features, partnerships, community involvement and marketing and communication strategies of urban fairs and markets.

Keywords: Urban Markets, Street Fairs, Craft Fairs, City of Oporto, Economic dynamics, Cultural experiences, Urban life

\section{Introdução}

A literatura científica sobre feiras e mercados urbanos é escassa. O tema é abordado de forma dispersa e, regra geral, enquadrado em análises de âmbito mais alargado sobre as dinâmicas económicas e culturais das cidades (Costa 2014; Crane 1992). Faltam abordagens específicas destas formas de comércio com origem e caráter tradicional, mas com novos formatos, características e envolvendo diferentes vivências. Existem lacunas ao nível da definição e uniformização de conceitos, da existência de um corpo teórico de referência e de um quadro analítico que sustente comparações em termos de formatos, características, causas e implicações. Por outro lado, não sabemos qual é o papel e o real impacto destas formas de atividade económica e das vivências culturais, sociais e lúdicas a elas associadas. Aliás, estes espaços de comércio e sociabilidade económica são matizados por dinâmicas de afirmação do-it-yourself (DIY) resultantes, na maioria das vezes, da reconfiguração profissional e artística de muitos dos seus protagonistas (Costa 2000; Costa 2008).

É consensual, não obstante, na documentação de instituições internacionais e de organismos locais que os mercados trazem vida aos lugares urbanos e favorecem a criação de sinergias entre agentes e a comunidade, constituindo experiências únicas de compras e sociabilização. Os mercados e as feiras urbanos envolvem diferenciados atores locais, que interagem em redes formais, através de parcerias institucionais, ou de relações informais, através de conhecimentos individuais ou colaborações organizacionais. Atraem consumidores e empreendedores e geram fluxos de pessoas que animam os espaços. Neste 
sentido, são considerados forças motrizes das vivências e do desenvolvimento económico local.

Na cidade do Porto, e em particular na Baixa portuense, têm surgido, em anos recentes, novos formatos de feiras e mercados, realizados em locais fechados ou ao ar livre, fixos ou móveis, e que têm associada uma maior ou menor componente cultural e lúdica. Nalguns casos, os mercados são variantes modernas das feiras de rua ou feiras de artesanato tradicionais, comercializando produtos tradicionais locais, regionais ou nacionais; noutros casos constituem formas de novos empreendedores (associados por vezes a microempresas) darem a conhecer o seu trabalho, alargando mercados de colocação dos produtos e chegando a novos públicos-alvo.

A presente pesquisa pretende ser um contributo para o estudo desta questão, através da sistematização de aspetos analíticos pertinentes. Focando o estudo na cidade do Porto, na atualidade, pretende-se apresentar um quadro de análise das feiras e mercados que constitua um contributo para outras investigações sobre o tema. Pretende-se também apresentar algumas evidências dos impactos das feiras e mercados na dinamização económica e social da cidade em geral e, em particular, dos locais (edifícios, ruas ou praças e respetiva área envolvente) onde ocorrem. Para o efeito foram utilizadas abordagens metodológicas diversificadas mas complementares: exploração de páginas eletrónicas institucionais e de páginas eletrónicas e do Facebook (quando existentes) das feiras e mercados da cidade; realização de entrevistas a responsáveis pela gestão e organização das feiras e mercados e observação direta dos mesmos. Nesta pesquisa, consideram-se todas as feiras e mercados da cidade que apresentam estas designações e que são reconhecidos legalmente pelo município para efeitos de atividade comercial retalhista, independentemente do seu caráter sedentário ou móvel, da sua periodicidade de ocorrência (periódicos e permanentes) ou da sua realização dentro de estruturas próprias ou em locais autorizados para o efeito (ruas e praças).

Em termos de estrutura, este artigo está organizado da seguinte forma: primeiro será feito um enquadramento de caráter teórico e analítico desta atividade económica; segue-se a análise das feiras e mercados existentes oficialmente na cidade do Porto na atualidade e, por fim, serão sistematizadas as principais conclusões. 


\section{As feiras e mercados urbanos na atualidade}

O setor retalhista sempre foi, é e será, pelo menos num futuro próximo, uma atividade urbana por excelência (Cachinho 2014). Nas cidades europeias este setor é complexo, multifacetado e diversificado, o que se deve às diferenças em termos de tipo de prestadores, modelos e organização de negócios, dimensão e formato dos pontos de venda, tipos de produtos, entre outros aspetos (CE 31/01/2013). Aqui enquadram-se todas as atividades de revenda de bens novos ou usados, destinados ao consumo de pessoas, empresas ou instituições, através de formatos diversos, entre os quais os estabelecimentos, as feiras e mercados, a venda ao domicílio ou por correspondência, a venda ambulante ou o comércio eletrónico (Barreta junho 2012). O setor retalhista é um elemento fulcral na vivência das cidades. A sua diversificação reforça os laços da comunidade, promove a coesão e contribui para a melhoria da qualidade de vida. A vitalidade e viabilidade do setor só podem ser conseguidas pela resiliência de diferentes e diversificadas atividades retalhistas (Barata-Salgueiro 2014). São visíveis, na atualidade, as fortes ligações entre regeneração urbana e o planeamento e resiliência do setor retalhista. As políticas urbanas são cada vez mais centradas na sustentabilidade das cidades, suportada pelo equilíbrio entre as dimensões económica, social e ambiental. Neste âmbito, é tido em conta o papel e importância das atividades retalhistas no desempenho económico das cidades (nomeadamente em termos de emprego e de suprimento das necessidades dos cidadãos) e na inclusão social (Fernandes and Chamusca 2014).

A atividade comercial desempenha um importante papel no desenvolvimento económico dos países e dos centros urbanos (OXIRM abril 2014). A atividade comercial retalhista tem uma longa tradição na Europa, estando na origem e acompanhando o desenvolvimento de muitas cidades (DCLG setembro 2010a; ENPI/CBCMED Sem data; URBACT março 2015), onde constitui a atividade económica principal, com um inegável impacto no que respeita ao emprego que gera (Fernandes 1997).

Na Europa, há registos da ocorrência de feiras e mercados pelo menos desde o século XII, enquanto locais de encontro periódico de mercadores profissionais e compradores (Pirenne 1946). No caso específico dos mercados públicos, a sua construção generalizou-se sobretudo a partir do século XIX, quando novos materiais e tecnologias construtivas se tornaram mais acessíveis e quando emergiu uma conceção burguesa de organização urbana, pautada pelo fortalecimento da separação funcional das atividades. Desde meados do século XX, com as melhorias tecnológicas ao nível da conservação dos alimentos, com a produção massificada e diversificada de bens, com o maior controlo da qualidade dos 
produtos e com a maior facilidade e rapidez da deslocação de mercadorias, os mercados foram preteridos em prol de outros formatos comerciais, como os supermercados ou hipermercados (Pintaudi 1/08/2006). Face a esta realidade muitos mercados sucumbiram, mas outros conseguiram sobreviver no tempo. Nas últimas décadas, em Portugal, as preocupações em torno dos mercados municipais têm-se centrado sobretudo nas condições higino-sanitárias, no estacionamento, na questão das acessibilidades e na concorrência das médias e grandes superfícies comerciais. Só muito recentemente se tem vindo a reconhecer o seu papel e importância enquanto atividade comercial retalhista (Barreta 11/03/2014).

Assim, as feiras e mercados tiveram desde sempre uma importante função económica, social e cultural para as cidades e para os seus cidadãos enquanto formas ou locais de comércio, de compra e venda de provisões e de bens diários ou não diários, de festivais, de relações sociais em comunidade e de fluxos de pessoas e informação. Constituem oportunidades de emprego, complementam a oferta comercial local, tornando a comunidade comercialmente mais atrativa. Para alguns segmentos de residentes, nomeadamente os grupos economicamente mais vulneráveis, estes formatos alternativos aos canais de distribuição moderna constituem modos de partilharem com os restantes segmentos da população a experiência do consumo de massas, com os signos, os códigos e a imagética cultural que Ihe está associada (Cachinho 2006). Para os idosos ou para os grupos pouco relacionados socialmente, o mercado (e aqui referimo-nos sobretudo ao mercado municipal, que se realiza de forma permanente, numa estrutura própria) pode representar uma das formas cruciais não só de aceder a bens do dia-a-dia como também de manter ou reforçar relações humanas e de amizade. Mais ou menos especializados, realizando-se dentro de edifícios (indoor markets) ou ocupando uma ou mais ruas ou praças, nas feiras e mercados da atualidade comercializa-se uma grande variedade de produtos. Não obstante, o seu impacto económico e social tem sido frequentemente subvalorizado (URBACT março 2015; WUWM 16/02/2011).

Nas últimas décadas testemunhou-se o incremento na oferta comercial e a alteração dos hábitos de consumo. As lojas tradicionais retalhistas que dominaram os centros urbanos europeus até aos anos 60 do séc. XIX foram perdendo sucessivamente importância. Multiplicaram-se e diversificaram-se especializações, formas e formatos e alteraram-se modos de operação, a dimensão financeira das empresas e as relações entre produtores e consumidores (Fernandes and Chamusca 2014). Os modos de pagamento são atualmente diversos e o acesso a bens e serviços tornou-se mais fácil. Em paralelo com os canais de distribuição tradicionais, existe hoje um leque de novas possibilidades que alteraram o 
mundo do comércio. Perante estas transformações, as feiras e mercados mantiveram-se quase estáticos (URBACT março 2015).

As feiras e mercados com simbolismo histórico têm tido grande significado na revitalização e no desenvolvimento económico e social das cidades, constituindo um elemento de animação urbana. Em muitos centros urbanos, as feiras e mercados tradicionais foram reinventados transformando-se em locais de modernização e inovação, quer pelos produtos comercializados quer pela forma de comercialização. Além disso, representam polos de comércio de caráter único e simultaneamente um património histórico e cultural (ENPI/CBCMED Sem data). Refira-se a este respeito, a importância que o mercado municipal ou algumas feiras tradicionais (de influência regional e/ou local) têm ainda nos dias de hoje na dinâmica dos centros das cidades, constituindo âncoras destas áreas (Barreta junho 2012).

Reconhecendo a importância das feiras e mercados nos planos económico, social e cultural existem diversos projetos internacionais que se debruçam sobre a potencialização de feiras e mercados. A nível europeu, o projecto URBACT Markets permitiu que nove cidades explorassem e partilhassem conhecimento e experiências quanto ao papel dos mercados urbanos enquanto forças motrizes do desenvolvimento económico local, da coesão social, da vivência e da regeneração urbana. O projeto é liderado por Barcelona (Espanha) e conta como parceiros Turim (Itália), Attica (Grécia), Suceava (Roménia), Pécs (Hungria), Wroclaw (Polónia), Londres (Reino Unido), Dublin (Irlanda) e Toulouse (França). ${ }^{1}$ Utilizando uma abordagem participativa e envolvendo uma grande diversidade de agentes, cada cidade, num processo de aprendizagem em rede com as outras cidades, construiu o seu próprio plano de ação local, adaptado às suas especificidades territoriais e aos seus próprios modelos de gestão e abordagem cultural dos mercados (URBACT março 2015). Também à escala europeia, o projeto Marakanda visa potencializar os mercados históricos do Mediterrâneo através da identificação de boas práticas e da transferência de conhecimento entre os parceiros. O projeto é coordenado pela cidade de Florença (Itália) e conta com a parceria do município e da universidade de Genoa (Itália), da União Regional de Municípios da Macedónia Oriental e Thrace (Macedónia e Grécia), do município de Limassol (Chipre), do Instituto Municipal de Mercados de Barcelona (Espanha), do município de Favara (Itália), da Souk El Tayeb Association (Líbano), do Centro de Investigação Nacional do Egito e do PLURAL - Centro de Estudos Europeus. ${ }^{2}$

\footnotetext{
${ }^{1}$ Mais informações em http://urbact.eu/urbact-markets.

${ }^{2}$ Mais informações em http://www.marakanda.eu/.
} 
A nível internacional, a World Union of Wholesale Markets (WUWM) é uma associação sem fins lucrativos que procura o reconhecimento da importância dos mercados grossistas e retalhistas nas cadeias de distribuição de alimentos a nível local, nacional e internacional. Visa promover a partilha de informação, conhecimento, experiências e competências sobre estes mercados, tendo em vista potencializar a sua construção, organização e gestão e promover a comunicação e colaboração entre autoridades públicas, entidades gestoras, produtores e vendedores. $^{3}$

\subsection{Conceitos, formatos e formas de gestão}

Tornando os centros das cidades mais vibrantes, os mercados podem assumir diversos formatos, dimensões e formas de gestão (NABMA Sem data).

Segundo a WUWM (16/02/2011), os mercados retalhistas consistem em unidades comerciais que, em local coberto ou ao ar livre, sob uma mesma unidade de gestão, representam estabelecimentos comerciais ou empreendedores retalhistas, providenciando uma oferta comercial variada de produtos alimentares e não alimentares. A National Association of British Market Authorities (NABMA) apresenta definições para diferentes tipos de mercados. Segundo esta associação, existem os "Mercados generalistas", que não são especializados em nenhum produto, sendo abertos a todos os tipos de vendedores; os "Mercados de produção local" que são focados em produtos locais (alimentação, artesanato, etc.) e os "Mercados especializados", que consistem numa mistura dos dois tipos de mercado anteriores, sendo distinguidos pelo facto de terem uma temática associada (mercado de arte, mercado de artesanato, mercado de produtos alimentares tradicionais, mercado de produtos vintage, etc.) (NABMA Sem data). O projeto Marakanda define mercado de forma mais generalista, como sendo um local de encontro entre vendedores ou lojistas e consumidores ou visitantes, com uma localização determinada e datas específicas de realização (ENPI/CBCMED Sem data).

A nível nacional, no Regime Jurídico de Acesso e Exercício de Atividades de Comércio, Serviços e Restauração (RJACSR) ${ }^{4}$, que regulamenta, entre outras atividades, a exploração de mercados municipais, de comércio a retalho não sedentário exercido por feirantes e a organização de feiras por entidades privadas, a definição de feira é a seguinte: evento que congrega periódica ou ocasionalmente, no mesmo recinto, vários retalhistas ou grossistas

\footnotetext{
${ }^{3}$ Mais informações em http://www.wuwm.org/.

${ }^{4}$ Decreto-Lei n.o 10/2015 de 16 de janeiro - Aprova o Regime Jurídico de Acesso e Exercício de Atividades de Comércio, Serviços e Restauração. In.: Diário da República, 1.a série, 16/01/2015, p. 454-499.
} 
que exercem a atividade com carácter não sedentário, na sua maioria em unidades móveis ou amovíveis, excetuados os arraiais, romarias, bailes, provas desportivas e outros divertimentos públicos, os mercados municipais e os mercados abastecedores, não se incluindo as feiras dedicadas de forma exclusiva à exposição de armas. No mesmo regulamento, mercado municipal constitui um recinto fechado e coberto, explorado pela câmara municipal ou junta de freguesia, especificamente destinado à venda a retalho de produtos alimentares, organizado por lugares de venda independentes, dotado de zonas $e$ serviços comuns e possuindo uma unidade de gestão comum. A nível local, a Câmara Municipal do Porto considera que uma feira é uma atividade de comércio a retalho não sedentária, exercida por pessoa que vende em recintos públicos ou privados, onde se realizem feiras e mercado consiste numa atividade de comércio a retalho, em recinto fechado (loja) ou estrutura inamovível (banca), destinado fundamentalmente à venda de produtos alimentares e de outros produtos de consumo diário generalizado (CMP - Balcão Virtual, consulta em 19/06/2015). ${ }^{5}$ O RJACSR designa de feira todos os eventos que, no que se verifica na realidade, designadamente no caso da cidade do Porto, podem assumir publicamente quer a designação de feira quer a de mercado. Apesar de fazer esta distinção, as definições apresentadas pelo município não permitem perceber com clareza o que é feira e o que é mercado (nos casos dos mercados que não se realizam em edifícios próprios).

No caso específico dos eventos com designação de mercados, segundo o URBACT, estes podem ser permanentes, realizando-se, regra geral, em local fixo e com estrutura própria, ou podem ser móveis, realizando-se ao ar livre, em ruas ou praças, ou aproveitando edifícios de utilidade diversa. Quanto à periodicidade, podem ser perenes (é o caso dos mercados fixos), periódicos ou esporádicos. Existem mercados onde se encontra um leque diversificado de produtos e outros que assumem um caráter especializado. Nestes últimos, encontram-se os mercados ou feiras de antiguidades, de produtos agrícolas, os mercados de peixe, de flores, de artesanato ou os Flea Markets (URBACT março 2015).

Um dos aspetos chave para a viabilidade e sucesso dos mercados é a forma como são geridos (DCLG setembro 2010b). As situações são diversas. Os principais modelos de gestão das feiras e mercados europeus são (DCLG setembro 2010b; ENPI/CBCMED Sem data; URBACT março 2015):

- Autoridades locais / setor público: este modelo tem como vantagem a consideração direta das feiras e mercados nos objetivos estratégicos locais, reconhecendo-se o

\footnotetext{
5 Informação disponível em http://balcaovirtual.cmporto.pt/PT/cidadaos/guiatematico/atividadeseconomicas/feirasmercadosevendaambulante/Paginas/default. aspx.
} 
bem público que constituem; em termos de desvantagens podem estar rodeados de demasiada burocracia, os recursos financeiros podem ser mais escassos e o tempo de resposta a desafios e problemas pode ser maior.

- Setor privado: neste modelo as feiras ou mercados podem ser de iniciativa privada ou, no caso de iniciativas públicas, concessionados a privados. As vantagens deste modelo relacionam-se sobretudo com a reduzida burocracia necessária para intervenções e com um elevado foco no core business, bem como com a capacidade de investir capital financeiro de forma direta. As desvantagens podem estar relacionadas com a reduzida responsabilidade social e numa menor proteção dos vendedores.

- Parcerias público-privadas: podem assumir diversos formatos (p. ex. a gestão estratégica pode ser da responsabilidade da instituição pública e a gestão operacional feita pelo setor privado) e durações; este modelo é útil sobretudo quando falta às autoridades locais capacidade para a gestão eficaz e eficiente do mercado e quando faz falta investimento financeiro; este modelo tem ainda a vantagem da concertação de interesses públicos e privados no desenvolvimento local, de uma maior disponibilidade, à partida, de recursos financeiros e da criação de economias de escala. A conciliação dos interesses públicos e dos interesses privados, no entanto, pode constituir um desafio.

- Parcerias entre o setor público: são uma variação das parcerias público-privadas, mas neste caso envolvendo diferentes organismos públicos.

- Associações comunitárias ou de caridade, cooperativas ou empresas com fins sociais: uma vez que o enfoque destas organizações são as questões sociais, a vantagem deste modelo consiste no compromisso para que a atividade comercial se processe de forma ética, gerando valor social e/ou benefícios ambientais, podendo haver uma maior proximidade com a comunidade face a outros modelos. O acesso a investimentos alternativos pode ser potencializado por via dos conhecimentos e ligações da organização gestora com outros agentes. Como desvantagem principal, poderá ocorrer falta de experiência na gestão de mercados.

- Vendedores / comerciantes: a principal vantagem consiste no forte envolvimento no sucesso do mercado e no sentimento de pertença e apropriação do mesmo, bem como na relativa reduzida burocracia; quanto às desvantagens, de referir que os recursos financeiros para investir podem ser escassos, pode haver lacunas ao nível das competências em gestão de negócios e podem ocorrer conflitos de interesses 
que se não forem resolvidos podem pôr em causa o objetivo comum do sucesso do mercado.

- Voluntariado: alguns mercados, geralmente focados na comunidade, com periodicidade pouco frequente e de relativa pequena dimensão, são geridos por voluntários, com as vantagens de se criar um sentimento de pertença à comunidade e de redução dos custos operacionais. Como desvantagens, apontam-se a limitada frequência de ocorrência, a falta de capacidade de investimento e a possibilidade de haver lacunas ao nível da gestão dos mercados.

Um mercado só pode funcionar eficazmente a longo prazo se for economicamente sustentável. Para isso, é importante que todas as decisões tomadas ao nível da sua gestão tenham em vista assegurar que os vendedores têm um negócio proveitoso e que a oferta do mercado vai ao encontro das necessidades e expectativas dos consumidores. No caso da abertura de novos mercados, existem alguns fatores a ter em consideração para que sejam bem-sucedidos, como por exemplo a localização, a relação entre qualidade e preço dos produtos, o horário, as facilidades e comodidades (bancos, casas de banho, etc.), o profissionalismo na relação comerciante - consumidor ou a estratégia de promoção e comunicação e a manutenção do edifício ou espaço público. Uma gestão eficaz deve ter liderança e ser visionária e inovadora. Deve refletir as aspirações locais e capacitar os agentes envolvidos, ser credível aos olhos da comunidade, ter capacidade de atrair e manter investimento e tornar o mercado um foco central da área envolvente e da cidade (URBACT março 2015).

\subsection{Oportunidades e desafios para o desenvolvimento local}

As feiras e mercados apresentam inúmeras oportunidades e benefícios: económicos, sociais, culturais e ambientais (DCLG setembro 2010a; NABMA Sem data; URBACT março 2015). Criam e mantêm oportunidades de emprego e de empreendedorismo. Em termos de empreendedorismo, constituem oportunidades para pessoas com negócios mostrarem os seus trabalhos, produtos e competências (NABMA Sem data; URBACT março 2015). A criação de emprego é feita quer por via de pessoas que trabalham diretamente nos mercados, quer através da cadeia de produção, transporte e distribuição dos produtos, com toda a logística e serviços envolvidos. Deste modo, os mercados direta e indiretamente geram emprego para trabalhadores com baixas qualificações profissionais, bem como para trabalhadores mais especializados. Muitos mercados europeus são autênticas atrações 
turísticas (Figura 1). ${ }^{6}$ A sua atratividade turística prende-se com o facto de darem uma perspetiva concentrada dos produtos tradicionais locais e, através deles, da vida típica local, dos hábitos e valores sociais e culturais. A maior afluência de consumidores habituais ou de visitantes e turistas pode significar o aumento do volume de venda do mercado e até mesmo do comércio envolvente, contribuindo, assim, para o crescimento económico local.

Os mercados podem complementar e melhorar a oferta retalhista existente na comunidade ou até na cidade, sobretudo quando existem ligações de cooperação entre o mercado e os estabelecimentos comerciais da envolvente. Podem contribuir para aumentar a competitividade interna (entre os vendedores) ou externa (com outros retalhistas), trazendo benefícios para os consumidores em termos de relação qualidade-preço dos produtos. Em comunidades deprimidas, os produtos - em particular os frescos - são muitas vezes vendidos a preços mais acessíveis, ligeiramente mais baratos do que nos supermercados ou hipermercados. A questão da segurança é de toda a pertinência. Sendo locais com elevada concentração de pessoas, podem propiciar certos tipos de criminalidade (como roubos, entre outros), pelo que assegurar que a segurança é um facto e transmitir essa mensagem é tornar os mercados mais convidativos para os visitantes. Quer os mercados permanentes que se realizam em estruturas próprias quer os mercados móveis ocupam uma porção específica do espaço urbano, tendo implicações no fluxo de pessoas e bens e, nalguns casos, no tráfego automóvel. Qualquer intervenção a este nível, enquadrada nas políticas de planeamento urbano, pode contribuir para a geração de mais-valias, pela criação ou renovação do espaço público, criando-se novos polos de atração de pessoas ou desenhando-se novos elementos icónicos na cidade, e pela melhoria da qualidade de vida urbana. A realização de mercados e feiras pode constituir um estímulo para a reabilitação de edifícios históricos, alavancando a reabilitação das áreas envolventes. Os espaços públicos renovados, quando convidativos à fruição, podem ser utilizados pelos cidadãos para lá do horário de funcionamento das feiras ou mercados, constituindo assim espaços de sociabilização e de vivências urbanas (URBACT março 2015; WUWM 16/02/2011).

As feiras e mercados podem estabelecer com a envolvente ligações económicas, sociais, ambientais e culturais fortes e positivas, com as quais lucram não só as feiras e mercados, mas também a envolvente. Com base nestas ligações, as feiras e mercados podem contribuir para o desenvolvimento urbano sustentável (NABMA Sem data). Não obstante a

\footnotetext{
${ }^{6}$ A título exemplificativo, referimos os mercados de Sant Antoni, Santa Caterina e La Boqueria em Barcelona (Espanha), o Borough Market, o Camden Lock, o Portobello Market, e o Brick Lane em Londres (Reino Unido), o Saint John Market em Wroclaw (Polónia), o Saint-Cyprien em Toulouse (França) e os famosos mercados da pulga de Paris (França) - Saint-Ouen, Montreuil e Aligre.
} 
situação dos mercados e feiras variar consideravelmente nas cidades europeias devido a diferentes regulamentações, modelos de gestão e fatores culturais, é possível apontar alguns desafios chave, como sejam a orientação para o consumidor; a elevada competição exercida por supermercados e hipermercados; a existência de uma gestão eficaz e eficiente; a criação de uma estratégia de comunicação com o comércio retalhista de proximidade; de uma estratégia de marketing para atração de consumidores; o investimento, nalgumas cidades, em infraestruturas ou na reabilitação dos edifícios (no caso dos mercados indoor) e, por fim, a existência de compromisso político e a valorização dos benefícios dos mercados (que muitas vezes não acontece por falta de dados e informação que comprovem a sua importância). Recentemente algumas cidades europeias apostaram fortemente na imagem dos seus mercados, criando marcas, logótipos, newsletters, publicações, programas educacionais para escolas e divulgação na imprensa ou nas redes sociais (como o Facebook ou o Twitter). As formas de divulgação mais simples e baratas são muitas vezes bastante eficientes: o passa palavra continua a ser eficaz, a participação em concursos e outros eventos e o convite de alguém conhecido para vir ao mercado são formas de aumentar a sua visibilidade (NABMA Sem data; URBACT março 2015; WUWM 16/02/2011).

\subsection{Estratégias de desenvolvimento e potencialização}

Aspeto fundamental para o desenvolvimento de uma estratégia de ação eficaz é o diálogo entre os agentes, a fim de haver coordenação ao nível das suas necessidades, interligandoas com as oportunidades de desenvolvimento dos mercados. Os agentes devem ser envolvidos, desde o início, no desenvolvimento da estratégia. Podem ser elencadas quatro etapas neste processo: i) construir um grupo de suporte à definição da estratégia que represente os agentes envolvidos; ii) efetuar o diagnóstico da situação; iii) definir a visão, os objetivos e as ações e iv) desenvolver estruturas e procedimentos. O grupo de suporte representa os agentes relevantes para o desenvolvimento conjunto de uma estratégia de ação, permitindo o reconhecimento, a compreensão e a coordenação dos interesses e das necessidades uns dos outros e o desenvolvimento de soluções sustentáveis próximas aos mesmos. O envolvimento de todos num propósito comum permite que estes atores se identifiquem com a visão, os objetivos e as ações. A visão consiste nas aspirações para o mercado no futuro. Reflete o modo como o município, a entidade gestora e os restantes agentes veem o mercado e a sua relação com a comunidade a longo prazo. Constitui o quadro de referência para a dedução de objetivos e de ações. Um dos métodos para identificar a visão consiste em transformar os desafios, as oportunidades e as necessidades 
identificadas durante o diagnóstico da situação em mensagens positivas. A discussão e o debate públicos podem ser ferramentas importantes na construção de uma visão sólida e com a qual agentes e cidadãos se identifiquem. Os objetivos operacionalizam a visão no que diz respeito ao desenvolvimento do mercado, à sua integração na comunidade e apropriação pela mesma. As ações concretas são definidas com base nos objetivos e tendo em vista a concretização destes. Uma estratégia de potencialização dos mercados funciona eficazmente se tiver um caráter integrado, isto é, se não for uma estratégia para o mercado, mas sim uma estratégia para o comércio local, que considere o mercado e todas as outras formas de comércio como diferentes formas de oferta capazes de atrair consumidores (ENPI/CBCMED Sem data; URBACT março 2015).

\section{As feiras e mercados na cidade do Porto}

O comércio a retalho está interligado à cidade do Porto desde a sua origem, sendo um aspeto fulcral na compreensão do seu desenvolvimento (Fernandes 1997). As feiras e mercados têm uma longa história no Porto, dinamizando e acompanhando o crescimento económico da cidade e promovendo a animação urbana. Ao longo do tempo, e face à crescente importância dos estabelecimentos comerciais fixos e dos novos formatos de comércio retalhista, as feiras e mercados foram perdendo vitalidade e relevância. $\mathrm{Na}$ atualidade, subsistem ainda feiras e mercados de caráter tradicional, herdadas de há muito tempo atrás. Ao mesmo tempo, nos últimos anos, têm surgido novas formas de mercadejar, voltadas não só para a prática comercial mas também para a animação e a vivência cultural e social do espaço urbano. Constitui nosso objetivo caracterizar e compreender a diversidade de mercados e feiras que existem no Porto nos dias de hoje, enquadrando-as no tempo e no espaço e analisando diferenças e similitudes. Nesta pesquisa, consideramos todas as feiras e mercados da cidade que apresentam estas designações e que são reconhecidos legalmente pelo município para efeitos de atividade comercial retalhista, independentemente do seu caráter sedentário ou móvel, da sua periodicidade de ocorrência (periódicos e permanentes) ou da sua realização dentro de estruturas próprias ou em locais autorizados para o efeito (ruas e praças).

Constituem objetivos desta investigação, por um lado, sistematizar um quadro de análise das feiras e mercados que constitua um contributo para outros estudos em torno deste tema, aplicando-o ao caso das feiras e mercados ativos na atualidade no Porto. Por outro 
lado, pretende-se apresentar evidências de que as feiras e mercados contribuem para uma maior vivência dos espaços onde ocorrem e da sua envolvente e, deste modo, para a sua dinamização económica e social.

Em termos metodológicos, foram utilizados procedimentos diversos mas complementares: i) consulta de literatura científica, páginas eletrónicas e relatórios relativos a projetos relacionados com esta atividade económica como suporte para o enquadramento teórico e conceptual e para a definição do quadro analítico do estudo de caso aqui apresentado; ii) consulta de bibliografia sobre a evolução dos mercados e feiras na cidade do Porto, a fim de ter uma perspetiva evolutiva desta atividade económica na cidade; iii) exploração e análise dos conteúdos de sítios eletrónicos institucionais (o da Câmara Municipal do Porto e o Portal do Turismo do Município), de notícias recentes e dos sítios eletrónicos e páginas das redes sociais dos mercados e feiras, quando existentes; iv) pedidos de informação ao município; v) entrevistas aos responsáveis pela gestão e organização das feiras e mercados e vi) observação direta dos eventos.

Em termos analíticos interessa analisar em que locais ocorrem (sejam móveis ou fixos, indoor ou outdoor), com que periocidades, horários e tipos de produtos comercializados, quais os modelos e entidades de gestão (setor público, setor privado ou outras instituições; entidade única ou parceria). Interessa avaliar as motivações que sustentam a realização de eventos em simultâneo, quais os mecanismos de financiamento e as estratégias de comunicação e marketing que utilizam. É também importante analisar as redes de parcerias institucionais e as colaborações informais e os níveis de envolvimento das comunidades locais e do comércio retalhista da proximidade.

\subsection{Breve evolução histórica}

Desde inícios do século XV que há registos da realização de feiras e mercados na cidade do Porto (Fernandes 1989/90), constituindo os principais locais de troca de bens e de escoamento do que era produzido na cidade (Fernandes 1997). Desempenhavam então um importante papel no abastecimento diário das populações (residentes na cidade ou nos espaços circundantes), numa época em que não estava ultrapassado o problema da conservação dos alimentos (Silva janeiro 2015). Para além disso, eram um importante fator de desenvolvimento económico e de afirmação do Porto à escala regional (Fernandes 1997). Foi sobretudo a partir do século XVII que se deu um incremento nesta forma de vender e adquirir produtos, que assumiam um caráter efémero ou continuado no tempo, mas com alteração de localização. Ocorriam feiras francas e feiras especializadas, com periodicidades 
diversas (anuais, bianuais, mensais, semanais e diárias). Representavam não só um evento mercantil para vendedores e consumidores, mas também um hábito social, uma forma de convívio e sociabilização para os residentes do Porto ou para os que se deslocavam à cidade para "ir à feira". Em termos económicos, contribuíram para reforçar o papel da cidade enquanto polo central de trocas comerciais, num tempo em que os estabelecimentos fixos tinham ainda pouca representatividade. O século XVIII ficou marcado pelo processo de crescimento da cidade e de afirmação económica, urbanística e arquitetónica (Fernandes 1989/90). O edificado passou a simbolizar o elemento de estruturação urbana, fundamental para a delineação de novos arruamentos, procurando-se a especialização dos espaços, ao contrário da multifuncionalidade de ruas, praças e largos que caracterizou todo o período medieval (Silva janeiro 2015). Ao longo do século XIX, verificou-se um aumento significativo do número de feiras, o que pode ao que parece ser atribuído à procura crescente resultante do crescimento populacional que ocorreu no Porto até ao início do século XX e ao qual os estabelecimentos comerciais fixos não conseguiam dar ainda eficazmente resposta. As feiras impulsionaram o desenvolvimento económico da cidade, ditando a ocupação funcional de muitas ruas e praças e, nalguns casos, contribuindo para a especialização do comércio fixo de determinados arruamentos. Não obstante, o reforço da importância do comércio fixo e a modernização económica e urbanística que ocorrem simultaneamente vão ditando o declínio e afastamento das feiras para a periferia, para fora de um centro onde começam a surgir estabelecimentos de requinte e portanto considerado impróprio para ocupações de caráter "rural" (Fernandes 1989/90; Fernandes 1997). Decorrendo do aumento da atividade comercial verificada no início do século XIX e do tráfego crescente de pessoas, bens e animais, característico de uma cidade em crescimento, apareceram novos produtos e novos tipos de comércio e serviços (Fernandes 1989/90). Num quadro de industrialização capitalista liberal, o comércio fixo afirmou-se face à atividade comercial não fixa, associada em larga medida à produção oficinal pré-industrial, num período marcado por transformações ao nível da reestruturação funcional do espaço urbano do Porto (Zilhão 2015). No mesmo período, foram aplicadas novas regulamentações, nomeadamente relativas à venda ambulante, tendo-se criado espaços cobertos próprios para o efeito (Silva janeiro 2015). Estes espaços, os mercados, funcionavam nos dias úteis da semana, surgindo sobretudo de preocupações higienistas e com a centralização das feiras que se realizavam de forma avulsa. Entre eles contavam-se os Mercados do Anjo (aberto em 1839), do Bolhão (aberto em 1841), do Peixe (aberto em 1874) e os Mercados da Aguardente, do Campo 24 de Agosto (ambos a funcionar em 1880) e o de Ferreira Borges (construído em 1885 e em funcionamento em 1888) (Fernandes 1989/90; Fernandes 1997). O século XX pauta-se pelo 
desaparecimento de muitas feiras e pelo encerramento de mercados. Sobrevive o Mercado do Bolhão (remodelado e ampliado em 1915) e são abertos os Mercados do Bom Sucesso (em 1952) e da Foz. O Mercado Ferreira Borges, apesar de não ser destruído, deixa de ter a função comercial. A partir da década de 60 do mesmo século são criados mercados de levante de pequena dimensão por toda a cidade, sobrevivendo algumas feiras tradicionais. Na década de 90 do século XX, dá-se um ressurgimento e revalorização das feiras e mercados (Fernandes 1989/90; Fernandes 1997). Os mercados em edifícios são de dimensão e influência diferenciadas. Os Mercados do Bolhão e do Bom Sucesso têm claramente uma área de influência superior aos demais: o primeiro, dada a localização central, é utilizado não só pela população que reside na parte central e oriental da cidade, como por muitas pessoas que se deslocam ao Porto para fazer compras; o do Bom Sucesso atrai sobretudo residentes da parte ocidental da cidade e dos concelhos de Vila Nova de Gaia, Matosinhos e Maia. Neste período, os mercados e feiras surgem na ordem do dia enquanto preocupações. São considerados fatores de animação urbana e de qualidade de vida e não meramente como equipamentos ou eventos ao serviço da população. É reconhecida a sua importância para a revitalização das cidades, sobretudo dos centros urbanos (Fernandes 1989/90). O seu desenvolvimento e reconhecida importância estão associados não só ao abastecimento de produtos frescos e aos baixos preços praticados como também à valorização da relação próxima entre vendedor e comprador proporcionada por esta atividade comercial (Fernandes 1997).

\subsection{Velhos e novos formatos de mercadejar na atualidade}

Atualmente, o Porto tem 24 feiras e mercados (Figura 3) a operar de forma oficial no setor retalhista. A sua localização é concentrada sobretudo na parte central da cidade (Figura 2). Do total, 21 têm um local de realização fixo; 2 mercados de rua ocorrem frequentemente num local, no entanto, podem, em caso de oportunidade, realizarem-se noutros locais pelo que foram classificados como "Fixa / Móvel" quanto ao tipo de localização; o restante mercado é realmente itinerante.

Em termos de mercados permanentes com estrutura fixa, existem na cidade quatro edifícios com a designação de Mercado. Dois deles - Mercado Ferreira Borges ${ }^{7}$ e Mercado

\footnotetext{
${ }^{7}$ O Mercado Ferreira Borges foi concessionado ao Hard Club por um período de 17 anos, tendo neste seguimento sofrido obras de reabilitação que se iniciaram em meados de 2009 e terminaram em setembro de 2010. Desde então, o espaço interior é constituído por núcleos diferenciados. Dispõe de uma nave central que serve para albergar exposições, para a realização de pequenos concertos, declamação de poesia ou para a realização de feiras artesanais. As naves laterais estão compartimentadas em espaços que se destinam a uma
} 
Abastecedor $^{8}$ - têm especificidades que não se enquadram no foco de análise deste trabalho. Os outros dois são o Mercado do Bolhão e o Mercado do Bom Sucesso que pela sua singularidade e por constituírem espaços simbólicos da cidade serão aqui apresentados de forma mais detalhada.

- O Mercado do Bolhão (Figura 4), localizado em pleno centro do Porto, representou durante décadas um ícone comercial da cidade devido à sua localização central, às suas características populares e à variedade, qualidade e preço dos produtos vendidos. A partir, sobretudo, dos anos 80 do século $X X$, com o desenvolvimento de outras formas de comércio e face aos novos hábitos de consumo, tem vindo a sofrer uma progressiva desvitalização e perda de importância enquanto local de abastecimento de bens alimentares perecíveis (CMP 1992). Paralelamente, as estruturas degradaram-se e acumularam-se condições de insalubridade. Continua, no entanto, a ser o mercado mais emblemático do Porto, tendo sido classificado como imóvel de interesse público em 2006. Em abril deste ano foi divulgada publicamente pela autarquia a intenção de iniciar a curto prazo o processo de reabilitação do edifício.

- O Mercado do Bom Sucesso (Figura 5) sofreu uma reabilitação recente ao nível da sua estrutura, reabrindo em 2013 com novas valências - hotel e escritórios. $\mathrm{Na}$ atualidade apresenta um novo conceito de mercado, mais moderno e voltado para um comércio mais sofisticado. Em 2011, foi classificado como imóvel de interesse patrimonial e monumento de interesse público pelo Ministério da Cultura e IGESPAR. Em 2014, o edifício do mercado conquistou o Prémio Nacional de Reabilitação Nacional e foi um dos vencedores dos Global Awards for Excellence, promovidos pelo Urban Land Institute de Nova Iorque.

A Câmara Municipal do Porto, através da Porto Lazer em articulação com o Pelouro da Fiscalização e com a Polícia Municipal, está a desenvolver uma avaliação da situação dos

\footnotetext{
livraria, a sala de ensaios, estúdios de gravação e a salas principais onde se realizam concertos, sessões de teatro e outras performances diversas. No piso superior situa-se a cafetaria.

${ }^{8} \mathrm{O}$ Mercado Abastecedor do Porto abriu a 8 de janeiro de 1988. É gerido por uma empresa de interesse público, constituída sob a forma jurídica de sociedade anónima. Constitui uma plataforma comercial grossista que é sede de cerca de 250 empresas que lá desenvolvem a sua atividade comercial. Com uma área total de 12 hectares, tem 6 pavilhões hortofrutícolas, 2 pavilhões de Cash \& Carry, um pavilhão de carne e peixe, um pavilhão de flores e um pavilhão de serviços técnicos. Tem ainda dois restaurantes, um stand de exposições, um auditório e um posto de abastecimento de combustíveis. Tem ainda 1.100 lugares de estacionamento para diversas categorias de veículos, desde ligeiros até grandes camiões frigoríficos. Os principais clientes do Mercado são comerciantes retalhistas e grandes consumidores do Porto, Grande Porto e até Região Norte. Integra a União Mundial dos Mercados Grossistas.
} 
mercados de cariz mais moderno a fim de criar uma marca - "Mercados Urbanos/Urban Markets - Porto" (MUUMP) - que constitui uma forma de associação institucional com o objetivo de garantir visibilidade e identidade comum a estes eventos. Os mercados enquadrados nesta estratégia são atualmente apoiados pela Porto Lazer, no decorrer do reconhecimento dos seguintes fatores: i) necessidade de revitalização/conquista de novos espaços na cidade; ii) promoção da animação geral; iii) reforço da programação em momentos altos de oferta da cidade e iv) alavancagem de novos eventos.

Em termos de responsabilidade pela gestão, 15 mercados e feiras são geridos pela administração pública (12 pela Câmara Municipal do Porto e/ou participadas - Porto Lazer e Fundação Porto Social - e 3 por juntas de freguesia), 5 são geridos por empresas, 1 mercado é gerido por uma associação, 2 mercados são geridos por particulares e 1 mercado é gerido através de uma parceria entre um instituto de ensino superior e uma associação. Quanto à periodicidade de ocorrência as situações são muito variáveis: há mercados e feiras que se realizam diariamente, outros que se realizam todos os fins de semana, outros ainda que são mensais; o Mercado Cedofeita Viva pela sua especificidade não tem uma periodicidade definida e, por fim, a Feira do Livro é um evento anual. Coexistem na cidade feiras e mercados de cariz tradicional com formatos mais modernos (Figuras 6, 7, 8 e 9). As feiras e mercados de caráter tradicional constituem oportunidades de encontrar produtos a preços mais acessíveis (por exemplo no caso dos bens alimentares perecíveis) ou pechinchas, constituindo, nessa medida, uma opção sobretudo para pessoas economicamente mais desfavorecidas ou, então, para curiosos ou colecionadores. Os formatos mais modernos são-no porque são inovadores, pelo menos na cidade, e porque apresentam novas formas de comprar e vender produtos tradicionais. Estes mercados e feiras são mais seletivos quanto aos produtos ou "marcas" expostas, selecionados e selecionadas com base em critérios específicos em linha com os objetivos dos eventos. Por outro lado, constitui seu objetivo divulgar esses produtos e promover pequenos negócios ou trabalhos de artesãos, abrindo novos mercados e dando-os a conhecer a novos públicos. Regra geral, estes mercados e feiras, comparativamente com os mais antigos, estão mais divulgados nos meios de comunicação eletrónica, através de páginas web específicas e, sobretudo, através de páginas no Facebook.

A aplicação do quadro de análise permitiu identificar alguns pontos fracos, nos quais seria pertinente atuar para a potencialização desta atividade económica. Desde logo, a informação relativa às feiras e mercados do Porto está incompleta e desatualizada no Portal 
do Turismo do Município ${ }^{9}$. A responsabilidade de gestão das feiras e mercados da competência da Câmara Municipal do Porto encontra-se dividida entre um serviço municipal e uma empresa participada da autarquia, o que não facilita a coordenação e uma estratégia de gestão integrada dos mesmos. Foi solicitada informação a diversos serviços (até se conseguir chegar ao serviço responsável na atualidade), sendo que o confronto dos dados obtidos são incoerentes nalgumas situações, o que se pode dever às diferentes datas de referência da informação. No entanto, denota a existência de informação dispersa e desatualizada e a incapacidade de resposta eficaz e cabal a um pedido de informação sobre os mercados e feiras. Verificou-se ainda que a abertura e celeridade para responder a questões e esclarecer dúvidas quanto aos mercados e feiras foram muito maiores nas situações em que a organização está a cargo de uma empresa de eventos ou entidade coletiva / associação do que nas situações a cargo do município ou juntas de freguesia (neste último caso não se obteve qualquer resposta).

\subsection{Mercados urbanos: a perspetiva dos responsáveis pela organização}

Os denominados mercados urbanos, de cariz mais moderno e inovador, que se diferenciam das feiras e mercados tradicionais pelos produtos comercializados, pela promoção de pequenos negócios e marcas, pela animação que lhes está associada e por trazerem novos públicos e vivências aos espaços urbanos, começaram a surgir em 2009 no Porto. A sua realização surge da consciência de que havia falta, na cidade, de iniciativas semelhantes às verificadas noutras cidades europeias.

A realização de 4 entrevistas semiestruturadas ${ }^{10}$, entre janeiro e setembro de 2015, à organização de mercados urbanos permitiu aferir aspetos que se explanarão de seguida.

O objetivo principal por trás do esforço de organização dos mercados prende-se em termos gerais com a dinamização dos espaços urbanos, a revitalização de áreas mais ou menos esquecidas e a animação lúdica e cultural de locais ou ruas, gerando fluxos de pessoas residentes, visitantes e turistas - e atraindo novos públicos, novos negócios, novas vivências.

\footnotetext{
9 A título exemplificativo, refira-se que no portal (http://visitporto.travel/Visitar/Paginas/Descobrir/ListaVisit.aspx?AreaType=3\&Area=30) é feita referência à feira o "Artesanato Urbano do Parque" que deixou de se realizar em 2012 (de acordo com o constante em http://artesanatourbanonoparque.blogspot.pt/, consulta a 24/06/2015).

${ }^{10}$ Foram entrevistadas as organizações dos seguintes mercados: Mercado Cedofeita Viva, Flea Market, Urban Market e Pink Market. Foram contactadas outras entidades, não se tendo obtido qualquer resposta.
} 
O Urban Market surgiu da perceção da quantidade de talentos escondidos, de amigos com projetos criativos que confidenciavam não saber como os promover, porque não se reviam nas feiras existentes mais tradicionais para promover o seu tipo de produto. Um conceito diferente dos já conhecidos mercados da cidade, com um posicionamento direcionado a produtos de autor, serviços, ativações de marca, lançamento de bandas de música, Dj's, entre outros. O Urban Market tem funcionado como uma rampa de lançamento para diversos criadores, uma forma de gerar micro negócios, de chegar a vários públicos (portugueses e estrangeiros). Nalguns casos tem permitido a exportação. É um desafio na inovação dos produtos, na exposição, no branding e nas tendências do mercado. Cada vez mais, em tempos de crise ou não, é importante cruzar áreas aparentemente distintas. Promover o contacto entre diversos negócios e valências, pôr as pessoas a conversar, pôr ideias a mexer. (Extracto da entrevista ao Urban Market)

Não existe lugar ideal, o nosso foco é o centro histórico do Porto, e dar a conhecer lugares e espaços que consideramos especiais, muitas vezes escondidos, outros desconhecidos, espaços que não são habitualmente frequentados, e que merecem ser partilhados, quer aos turistas quer aos habitantes da cidade. Misturar para encontrar: como por exemplo entrar num Hotel e descobrir o Urban Market, passear pela Estação de São Bento e seguir a música que vem de uma ruela e maravilhar-se com a colorida Praça das Cardosas e o Urban Market. (Extracto da entrevista ao Urban Market)

Tentamos sempre ter também uma vertente mais social e por isso costumamos sempre apoiar projetos de apoio social. Neste momento temos sempre connosco a Elsa Brilhante com o seu projeto Todos Juntos Pelo João. Dependendo do tamanho do evento e também das propostas que nos cheguem, podemos chegar a ter mais que um projeto por evento. Temos também sempre algum tipo de animação em conjunto com o mercado para dinamizar um pouco mais o evento, desde aulas $e$ performances de dança, concertos, oficinas, etc. Temos também sempre música ambiente. (Extracto da entrevista ao Pink Market)

Muito embora usufruam da pujança da atividade turística na cidade, ao contrário do que se verifica noutras cidades europeias, as feiras e mercados do Porto não são voltados principalmente para a captação de turistas. Embora atraiam algum consumo turístico, não se regista inflação nos preços dos produtos, nem uma oferta direcionada maioritariamente para a procura turística. O objetivo principal é captar pessoas, da cidade, do país, do estrangeiro. A Porto Lazer (empresa participada da Câmara Municipal do Porto) é uma parceira institucional fundamental. O seu apoio prende-se sobretudo com questões técnicas (som e alimentação) e burocráticas, com a concessão de licenças para utilização dos espaços, bem como com a divulgação dos mercados. Outras parcerias são estabelecidas pontualmente com empresas, organizações diversas ou pessoas individuais (músicos, atores, pintores, dançarinos e outros artistas) tendo em vista uma dada realização dos mercados numa determinada data. A ligação com a comunidade envolvente e, em particular, com os comerciantes da área, é uma preocupação constante, no sentido de gerar 
mais-valias recíprocas. Trazer os comerciantes para a rua ou local no dia do mercado e contribuir para a dinamização das suas lojas através do seu envolvimento no próprio mercado é um desafio tido em grande consideração pela organização dos mercados.

O comércio tradicional é um fator importante nos espaços onde vamos; é a ligação que criamos com quem já está no espaço, sejam lojas, restaurantes, respeitando e criando parcerias em que todos saem a ganhar. (Extracto da entrevista ao Urban Market)

Apesar de estar por estudar os impactos económicos que a realização dos mercados têm na envolvente e, até mesmo na cidade, os entrevistados, pela sua experiência e pelo que vivenciam na organização e durante a realização dos eventos, apontam alguns impactos visíveis da sua realização. Antes de mais, colocam as ruas ou os locais onde se realizam no "mapa da cidade". Geram maior movimento de pessoas nas ruas ou espaços, o que pode, na opinião dos entrevistados, gerar maior afluxo de clientes ao comércio na envolvente ou então tornar esse comércio conhecido de uma maior quantidade e diversidade de públicos. Este efeito é considerado prevalecente a eventuais queixas de comerciantes de que nesses dias não vendem tanto porque as pessoas compram nos mercados e não nos estabelecimentos comerciais fixos. Por outro lado, referem que há uma maior adesão ao longo do tempo por parte de vendedores (já existem listas de espera) e compradores.

Coincidência ou não (com o início do Projeto), de há 2 anos para cá, fruto da dinamização do centro da cidade, começou a circular mais gente na rua, começaram a surgir novos negócios... Considero que o Projeto ao dinamizar a rua, um pouco afastada do Centro Histórico, colocou-a no «mapa da cidade». A Câmara começou a vê-los como parceiros e a envolver-se nas suas atividades. Nos últimos tempos começaram a ser requalificados edifícios, negócios a fechar mas outros a abrir, convivendo com comerciantes resistentes cujos negócios sobrevivem há muitos anos... O impacto é bom não tanto pelo volume de vendas, que não está quantificado, mas sim pelo maior fluxo de gente na rua. Isto é que é impactante e se reflete nos outros dias, sem ser os dos mercados. Há por isso efeitos induzidos na economia da rua, que não ocorrem propriamente no dia, mas depois (pessoas que ao visitarem o mercado vêem determinada loja que lhes interessa e voltam lá mais tarde) e que se manifestam na circulação de pessoas, no facto de Cedofeita se manter na cabeça das pessoas e constar do mapa da cidade. (Extracto da entrevista ao Mercado Cedofeita Viva)

Atualmente é uma das maiores feiras/mercados urbanos realizados na cidade, que move mais de 200 vendedores e cerca de 1000 visitantes em cada edição. Acreditamos que o impacto na Baixa é grande e que ajudou a mudar o paradigma da segunda mão na cidade. (Extracto da entrevista ao FleaMarket) 
O estabelecimento de relações sociais entre vendedores, entre estes e clientes ou mesmo entre as pessoas que se encontram nos eventos, é considerado um impacto real e positivo dos mercados. Trata-se de promover o contacto entre pessoas e negócios, de criar condições para o estabelecimento de redes pessoais e profissionais que podem resultar em futuras ligações e trata-se também de criar um ambiente propício ao surgimento de novas ideias.

As páginas web e no Facebook são formas preferenciais de divulgação pelo seu alcance exponencial. A menção dos mercados em revistas de divulgação turística ou as entrevistas concedidas pela organização contribuem para a maior visibilidade dos mesmos. Também recorrem a press releases que enviam para a comunicação social e recorrem ainda a flyers e cartazes que são difundidos em locais estratégicos por toda a cidade (postos de turismo, agências de viagens, estabelecimentos hoteleiros ou de restauração, etc.).

Os entrevistados referem que na implementação da sua iniciativa sentiram dificuldades ao nível da obtenção das licenças necessárias, processo considerado bastante burocrático. $\mathrm{Na}$ atualidade, as condições meteorológicas são um problema para a realização de feiras e mercados ao ar livre e nem sempre é fácil encontrar locais apropriados - ou porque são privados e os proprietários não têm interesse em deixar ocupar o espaço, ou porque os espaços são pequenos ou, ainda, tratando-se de espaços públicos, a autarquia nem sempre está de acordo com os locais escolhidos. Por fim, referem a falta de apoio financeiro como um obstáculo na melhoria das condições dos eventos, quer para os vendedores quer para os compradores e demais visitantes e a inexistência de uma estratégia pública efetiva e eficaz de dinamização das feiras e mercados urbanos.

\section{Conclusões}

A literatura sobre feiras e mercados urbanos é escassa, existindo lacunas ao nível da definição e uniformização de conceitos, de um corpo teórico de referência e de um quadro analítico que sustente análises comparativas. É, não obstante, consensual por parte de organizações internacionais que as feiras e mercados tiveram e têm uma importante função económica, social e cultural nos centros urbanos, para além das referências simbólicas que Ihes estão associadas. Para além de constituírem de forma global formatos de comércio de caráter mais tradicional que resistem às formas de distribuição mais recentes, constituem também, na atualidade, atrativos turísticos. 
Nesta pesquisa pretende-se apresentar um contributo para a investigação neste tema através da análise das feiras e mercados a operar de forma oficial na cidade do Porto. $\mathrm{Na}$ atualidade, coexistem, na cidade, feiras e mercados mais tradicionais com formatos mais inovadores, quer pela seletividade dos produtos quer pela preocupação em promover pequenos negócios ou artesãos empreendedores, dando-os a conhecer a novos e diversificados públicos. As dinâmicas recentes das feiras e mercados do Porto, refletidas no seu ganho de importância e projeção nos últimos anos, podem dever-se, em certa medida, a uma aposta, ainda que embrionária, por parte do município no apoio institucional a eventos com a marca "Mercados Urbanos". No entanto, a pesquisa desenvolvida mostra também o seu contributo para atenuar os efeitos da crise económico-financeira, pela oferta de produtos usados e pelos preços praticados (produtos mais baratos comparativamente com outros formatos de comércio retalhista). A dinamização dos espaços urbanos, a revitalização de áreas "esquecidas", a animação lúdica e cultural, a criação de vivências urbanas e o envolvimento com o comércio envolvente são preocupações dos responsáveis pela organização de mercados e feiras de caráter mais moderno. As parcerias institucionais ou com empresas ou outras organizações são fundamentais, nalguns casos decisivas até, para a realização dos eventos. Por outro lado, as ligações e colaborações informais que se estabelecem e dinamizam são importantes quer para a realização dos eventos quer para a criação de conhecimentos entre pessoas e negócios, podendo resultar em colaborações futuras. Como aspetos menos positivos ou, se quisermos, desafios que se colocam para a potencialização desta atividade económica, sobressai a falta de informação atualizada e concentrada no caso das feiras e mercados da gestão da administração local, a significativa burocracia associada ao processo de criação e realização de uma feira ou mercado e a falta de apoio financeiro.

Por fim, a definição de uma estratégia integrada para dinamização das feiras e mercados constitui, por um lado, um desafio que se coloca à autarquia, tendo em vista a concertação de interesses públicos e privados num mesmo objetivo - o desenvolvimento desta atividade económica na cidade. Por outro lado, a consideração das feiras e mercados na estratégia global de desenvolvimento económico do Porto é simultaneamente um desafio e uma oportunidade tendo em vista obter resultados mais eficazes e eficientes nesta matéria a curto e a longo prazo. 


\section{Referências}

BARATA-SALGUEIRO, T. Retail planning and urban resilience - An introduction to the special issue. Cities, 2014, 36, 107-111.

BARRETA, J. Mercados Municipais em Portugal - Pouco(s) sabem dos seus e alguém quererá saber de todos? 11/03/2014. Available from

Internet:http://www.jornalarquitecturas.com/canal/detalhe/opiniao-de-joao-barreta-mercadosmunicipais-em-portugal--poucos-sabem-dos-seus-e-alguem-querera-saber-de-todos-.

BARRETA, J. Comércio de proximidade e regeneração urbana. Edtion ed.: CIP - Confederação Empresarial de Portugal, junho 2012. 87 p. ISBN 978-989-98323-1-2.

CACHINHO, H. Consumactor: da Condição do Indivíduo na Cidade Pós-Moderna. Finisterra, 2006, $\mathrm{XLI}(81), 33-56$

CACHINHO, H. Consumerscapes and the resilience assessment of urban retail systems. Cities, 2014, 36, 131-144.

CE. Comunicação da Comissão ao Parlamento Europeu, ao Conselho, ao Comité Económico e Social e ao Comité das Regiões: Criação de um Plano de Ação Europeu para o Setor Retalhista. In. Bruxelas: Comissão Europeia, 31/01/2013, p. 22.

CMP Sentir e Pensar os Mercados e Feiras do Porto. Edtion ed.: Câmara Municipal do Porto/Pelouro dos Mercados, Equipamentos e Serviços Técnicos, 1992. 210 p. ISBN 972-9147-06-X.

COSTA, P. Centros e margens: produção e práticas culturais na Área Metropolitana de Lisboa. Análise Social, 2000, xxxiv(154), 957-983.

COSTA, P. Creativity, innovation and territorial agglomeration in cultural activities: the roots of the creative city. In Creative cities, cultural clusters and local development. Cheltenham: Edward Elgar, 2008, p. $183-210$.

COSTA, P. 2014. Cultural districts and the evolving geographies of underground music scenes: the Bairro Alto case. In Proceedings of the KISMIF International Conference "Keep It Simple, Make It Fast: Underground Music Scenes and DIY Cultures", Faculdade de Letras da Universidade do Porto e Casa da Música - Porto - 8 a 11 de julho2014.

CRANE, D. The Production of Culture: Media and the Urban Arts. Edtion ed. Newbury Park: Sage, 1992.

DCLG. Retail Markets: A good practice guide [online]. Communities and Local Government Publications. Department for Communities and Local Government / UK Government, setembro 2010a. Available from World

Wide Web:<https://www.gov.uk/government/uploads/system/uploads/attachment data/file/5986/1712975. pdf $>$.

DCLG. Retail Markets: Management models [online]. Department for Communities and Local Government / UK Government, setembro 2010b. Available from World Wide Web:<https://www.gov.uk/government/uploads/system/uploads/attachment data/file/6014/1712972. pdf>.

Decreto-Lei n.o 10/2015 de 16 de janeiro - Aprova o Regime Jurídico de Acesso e Exercício de Atividades de Comércio, Serviços e Restauração. In.: Diário da República, 1.a série, 16/01/2015, p. 454-499.

ENPI/CBCMED. Marakanda - Mediterranean Historical Markets: Historical city markets guidelines. Sem data.

FERNANDES, J. A. R. As Feiras e os Mercados no Tecido Comercial do Porto. In Boletim Cultural. Porto: Câmara Municipal do Porto, 1989/90, vol. Volume 7/8, 2a Série, p. 351-377.

FERnANDES, J. A. V. R. Porto: Cidade e Comércio. Edtion ed. Porto: Arquivo Histórico da Câmara Municipal do Porto, 1997. 295 p. ISBN 972-605-045-6. 
FERNANDES, J. R. AND P. CHAMUSCA Urban policies, planning and retail resilience. Cities, 2// 2014, 36, 170-177.

NABMA. A toolkit for setting up a local market. Sem data.

OXIRM. Retail \& wholesale: key sectors for the European economy. abril 2014.

PINTAUDI, S. M. Os mercados públicos: metamorfoses de um espaço na história urbana. Scripta Nova [Type of Work]. 1/08/2006, vol. Vol. X, N. 218 (81), pp. 13. Available from Internet:<www.ub.edu/geocrit/sn/sn-218-81.htm>. ISSN 1138-9788.

PIRENNE, H. Medieval cities: Their origins and the revival of trade. Edtion ed. Princeton: Princeton University Press, 1946. 253 p.

SILVA, R. Espaço Urbano - O mais emblemático mercado da cidade. In O Tripeiro. Porto: Associação Comercial do Porto, janeiro 2015, vol. 7ạ Série, № 1, p. 10-11.

URBACT. Urban markets: heart, soul and motor of cities. C.O. BARCELONNA, março 2015.

WUWM. The Role and Importance of the Wholesale and Retail Market Sectors for the European Union. $16 / 02 / 2011$.

ZILHÃO, A. O Centro do Porto: Formação e Evolução (1850-2001). Edtion ed.: Editorial Novembro, 2015. 237 p. ISBN 978-989-8136-92-3.

\section{Agradecimentos}

Agradecemos a disponibilidade e atenção do Eng. José Magano (dinamizador do Mercado

Cedofeita Viva), da equipa da S.P.O.T. (Flea Market), da equipa da Portugal Lovers, Marketing \& Comunicação (Urban Market) e da equipa do Pink Movement (Pink Market). 


\section{Anexos}

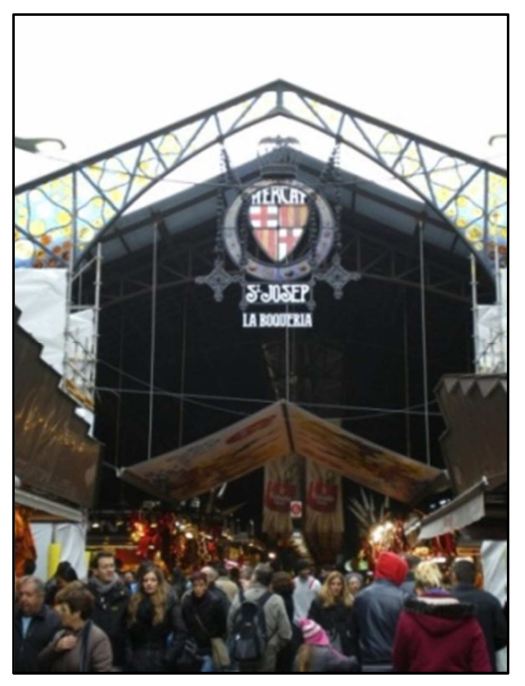

Figura 1 - Mercado La Boqueria, Barcelona, Espanha (dezembro de 2013). Fonte: Autoria própria.

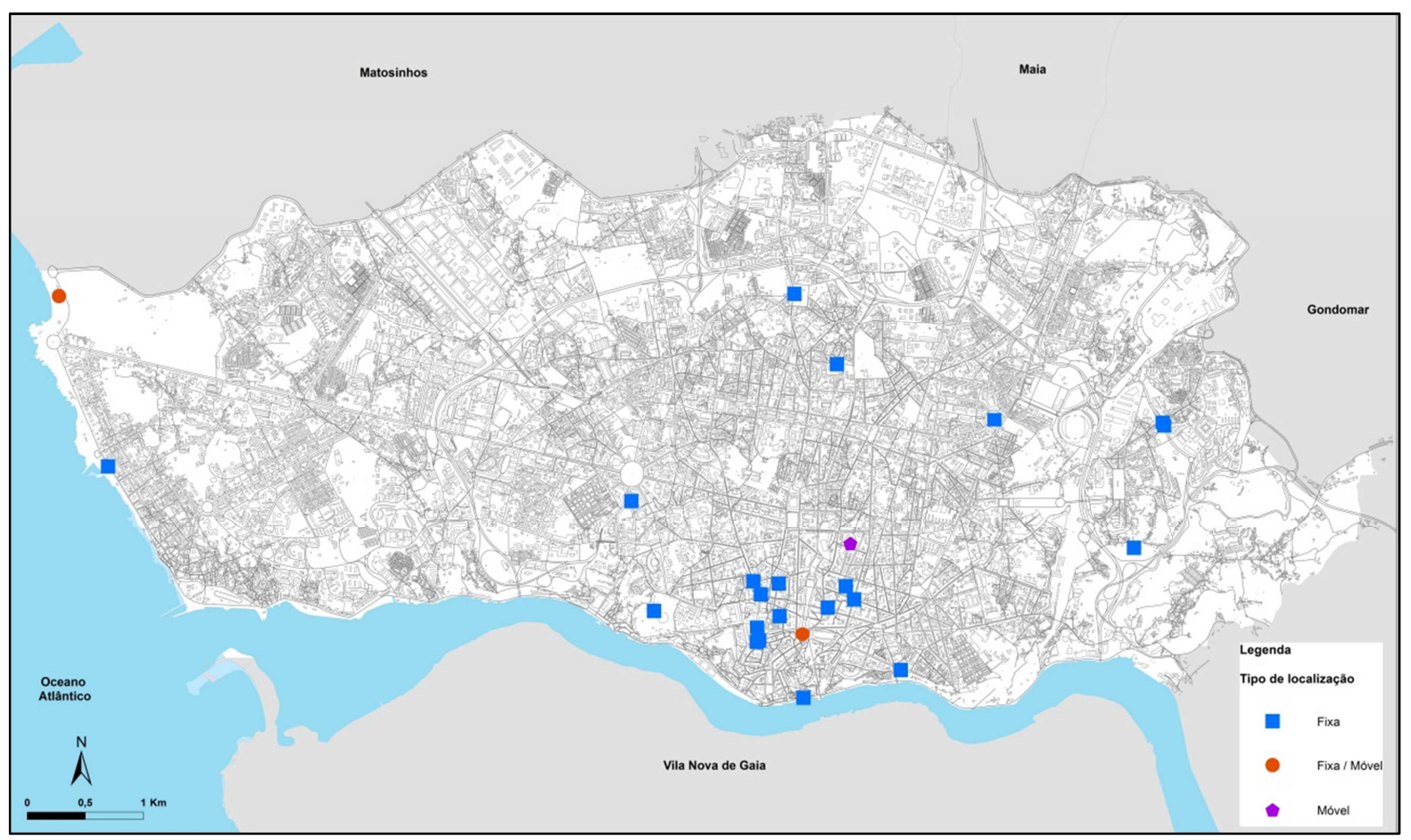

Figura 2 - Feiras e Mercados do Porto por tipo de localização em outubro de 2015

Nota: Os dois mercados com localização "Fixa / Móvel" estão representados nos locais onde é mais frequente a sua ocorrência: o Urban Market está localizado na Praça das Cardosas e o Pink Market está localizado no Edifício Transparente. O Flea Market, mercado que se pretende seja itinerante, está representado no local (Silo Auto) da última realização no Porto, a 17 de outubro de 2015, à data de entrega deste trabalho. O Mercado Ferreira Borges e o Mercado Abastecedor não se encontram georreferenciados, uma vez que não se enquadram no âmbito de análise deste trabalho. 


\begin{tabular}{|c|}
\hline Designação \\
\hline Mercado do Bolhão \\
\hline Mercado do Bom Sucesso \\
\hline Mercado de levante do Covelo \\
\hline Mercado do Cerco \\
\hline Mercado da Ribeira \\
\hline Feira da Vandoma \\
\hline Feira do Cerco \\
\hline Feira de Artesanato de Santa Catarina \\
\hline Feira de Numismática, Filatelia e Colecionismo \\
\hline Feira das Plantas e Flores \\
\hline Feira dos Passarinhos \\
\hline Feira de Antiguidades e Velharias \\
\hline Feira da Pérgola \\
\hline Mostra de Velharias e Antiguidades de Arca D'Água \\
\hline Mercado de Artesanato do Porto \\
\hline Feira do Mundo Rural \\
\hline Mercadinho dos Clérigos \\
\hline Mercado Porto Belo \\
\hline Mercado Cedofeita Viva \\
\hline Urban Market \\
\hline Flea Market \\
\hline Pink Market \\
\hline Feira do Livro do Porto \\
\hline The Real Vintage Market \\
\hline
\end{tabular}

Figura 3 - Feiras e Mercados existentes no Porto em outubro de 2015

Fonte: CMP/Porto Lazer, 2 de fevereiro de 2015 (dados pedidos); CMP/DMF/DMFAIVP, 3 de julho de 2015 (dados pedidos); páginas web e do Facebook dos mercados e feiras (quando existentes). Nota: A sigla CMP/DMF/DMFAIVP corresponde à Divisão Municipal de Fiscalização Ambiental e Intervenção na Via Pública, pertencente ao Departamento Municipal de Fiscalização da Câmara Municipal do Porto. 

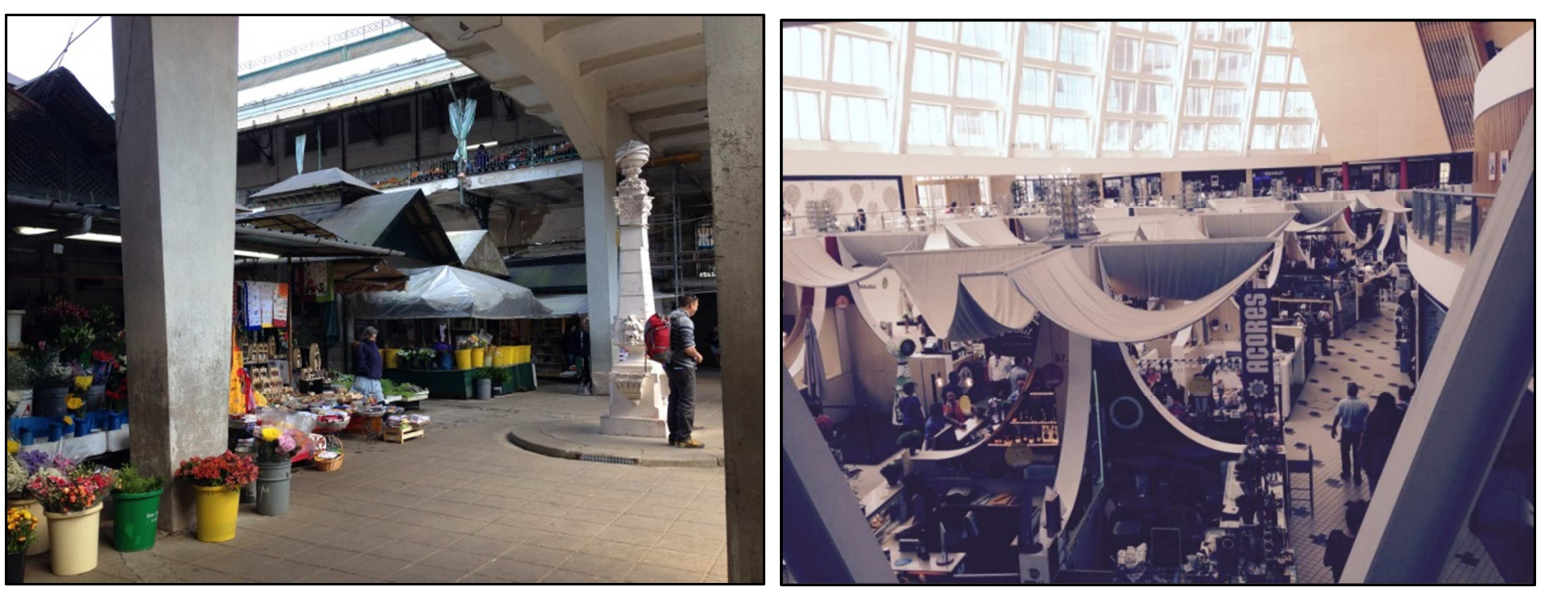

Figuras 4 e 5 - À esquerda, Mercado do Bolhão (15 de abril de 2015); à direita, Mercado do Bom Sucesso (3 de julho de 2015) Fonte: Autoria própria.
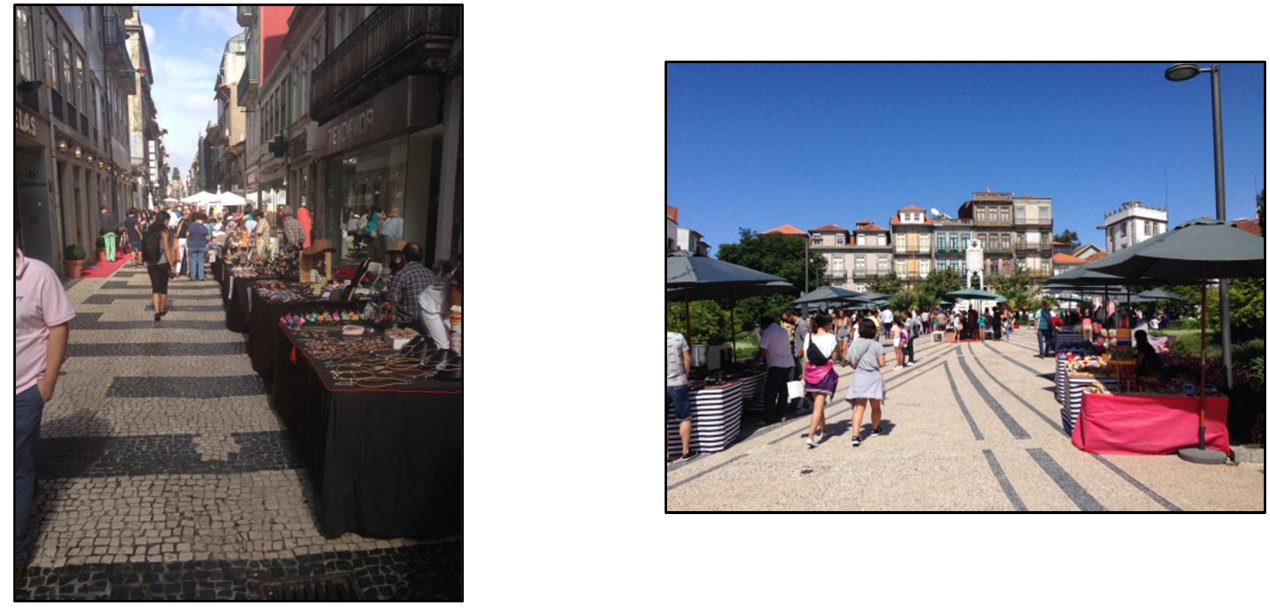

Figuras 6 e 7 - À esquerda, Mercado Cedofeita Viva (4 de outubro de 2014); à direita, Mercado Porto Belo (13 de setembro de 2014)

Fonte: Autoria própria.
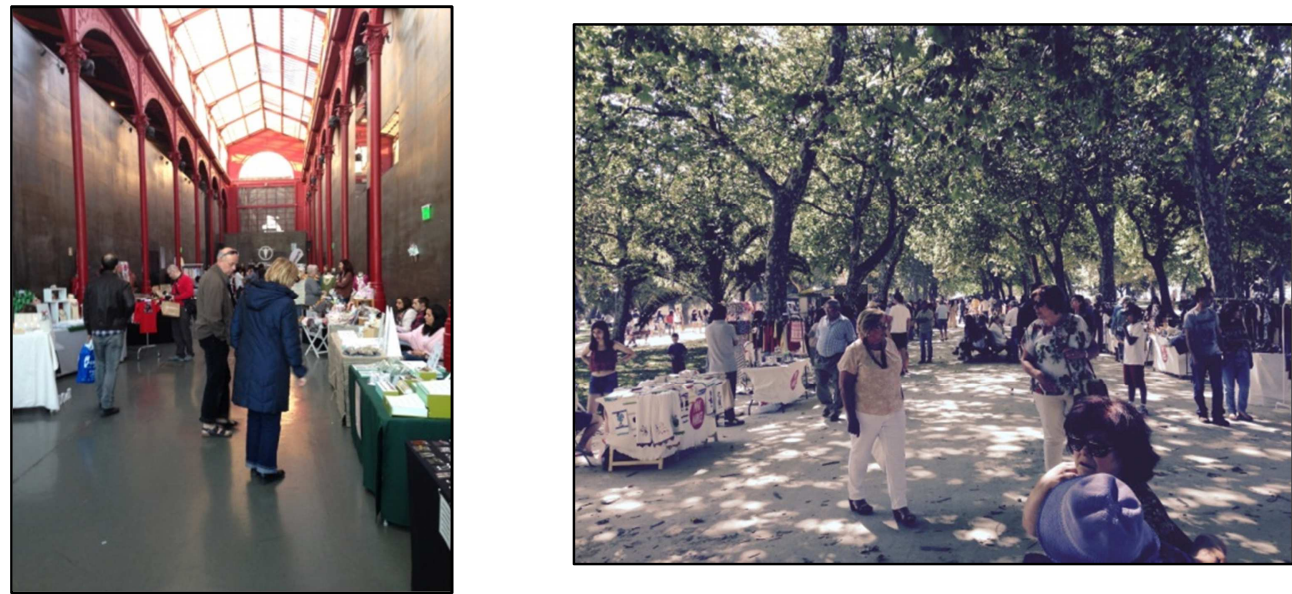

Figuras 8 e 9 - À esquerda, Urban Market, Mercado Ferreira Borges (14 de março de 2015); à direita, Pink Market, Jardins do Passeio Alegre (12 de julho de 2015)

Fonte: Autoria própria. 